\title{
Assessment of awareness, knowledge, attitude and practice regarding organ donation among medical teachers and post- graduate
}

\author{
Nayak Manjit', Khubchandani HT $^{2}$, Patani Kalpesh ${ }^{3}$, Dewangan Tikendra ${ }^{4}$
}

Received on April 06, 2019; editorial approval on June 26, 2019

\begin{abstract}
Introduction: Organ donation deals with the surgery which includes harvesting the organ and transplants them into end stage organ disease patient which on progression required organ transplantation surgeries. Organ donation rate in India is only 0.26 per million. ${ }^{1}$ Absence of consciousness about the requirement of organ donation and the unfamiliarity among medical fraternity regarding its significance knowledge and legal issues create the huge splintering for end stage organ disease Patient. The objective of this study is to assess the awareness, knowledge, attitude and practice regarding organ donation among the Medical Teachers, \& students perusing Post-Graduation. Materials and methods: Study was conducted among 100 subjects, where 50 Medical Teachers \& 50 students pursuing Post-Graduation have participated. Questionnaires are distributed in order to assess their awareness, knowledge, attitude and practice regarding organ donation among the Medical Teachers, \& students perusing PostGraduation. Collected Data was analysed using Microsoft Excel program. Results: Total 100 subjects participated in this study, among this 50 are Medical Teachers \& 50 are student pursuing post-graduation. Only 33\% have gone through the provisions of Transplantation of human organ \& tissue act, 1994, although 68\% among them have motivated the patient's relative for the organ donation. Conclusion: Requirement for organ donation have been showing tremendous upsurge trends as there are increased number of patients diagnosed with end stage organ disease. On the other side lack of awareness, knowledge, attitude and practice regarding organ donation shall hamper the current scenario for upgradation of health status among end stage organ disease patient.
\end{abstract}

Keywords: organ transplantation, end stage organ disease, brainstem death, Transplantation of Human Organs (THO) Act INTRODUCTION

Human organ and tissue transplantation were started in India in 1962. In the beginning, the organ transplant was unregulated, and organ trafficking was extensive. The act governing the transplantation was passed in 1994. This has been consequently modified in 2011, and new rules came into force in 2014. Many of the students as well as practicing physicians are not aware of the act as it is generally not a part of the syllabus. Organ transplantation is considered as the greatest advances of recent science that deals with organ retrieval, harvesting, and transplantation for end stage organ diseases for therapeutic purpose \& prevents their commercial dealings. The act was initiated at the request of Maharashtra, Himachal Pradesh, and Goa (who therefore adopted it by default) and was subsequently adopted by all states except Andhra Pradesh and Jammu and Kashmir. Despite a regulatory framework, cases of commercial dealings in human organs were reported in the media. An amendment to the act was proposed by the states of Goa, Himachal Pradesh, and West Bengal in 2009 to address inadequacies in the efficacy, relevance, and impact of the act. The amendment to the act was passed by the parliament in 2011, and the rules were notified in 2014. The same is adopted by the proposing states and union territories by default and may be adopted by other states by passing a resolution. There are some differences between act of 1995 and subsequent rules passed in $2014 .^{2-4}$
Address for correspondence:
${ }^{1}$ Tutor (Corresponding author)
Mobile:+919998227871
Email:manjit8889@gmail.com
${ }^{2}$ Associate professor
Mobile: +919427713663
Email: h_khub@yahoo.co.in
${ }^{3,4} 3^{\text {rd }}$ year resident doctor
Department of Forensic Medicine \& Toxicology, B.J
Medical college, Ahmedabad. 
The total number of road accident fatalities reported in 2013 in India was $1,37,572$, contributing to almost $1.1 \%$ of the world's total deaths. In nearly 40 to $50 \%$ of road accident fatalities, the cause of death has been head injury. ${ }^{5}$ These victims of head injury from road traffic accidents alone, are in enough numbers to meet the demand of potential donors of organs in the country. The total organ donation shortage of the country can be met with if even 5 to $10 \%$ of these persons involved in fatal accidents serve as organ donors. This is, however, an utopian situation and there are a number of barriers and challenges that are at play in achieving this goal of completely meeting the demands for organ donation. There is a great mismatch between the number of potential donors and actual cadaveric donors. Even in the case of individuals who have given consent for donation after death, the influences of the familial members might change the actual decision. Lack of awareness, superstitions, delay in funeral, lack of agreement between family members, fear of social criticism and dissatisfaction with the hospital staff might all influence their decision. It is here that the involvement of other stakeholders, non-governmental organizations and religious leaders would help in imparting awareness and knowledge and in changing the attitude of the general public towards deceased organ donation. Ultimately, the National Organ and Tissue Transplant Organization (NOTTO) needs to be strengthened so that it may play a central role in coordinating the activities of deceased organ donation. ${ }^{6}$

Clinical guidelines for determining brain death are not consistently validated by the presence of irreversible brain stem ischemic injury or necrosis at autopsy. They do not, therefore, completely exclude the reversible loss of integrated neurological functions in those certified as potential donors. Several critical brain structures remain viable and continue integrated neurological functioning after clinically determined brain (stem) death occurs. These include electroencephalogram activity, and hypothalamic functions. A recent review of the clinical literature ${ }^{7}$ found evidence that suggested preservation of the hypothalamic function in a substantial proportion of patients declared dead by the neurologic criteria. Approximately half of the patients reported in the literature showed evidence suggesting the presence of osmoregulation via the regulated secretion of vasopressin (anti- diuretic hormone). A substantial proportion of patients were also secreting hypophysiotropic hormones originating in the hypothalamus. Patients with preserved cortical electrical activity or intracranial blood flow are considered to be dead in countries that utilize a brain stem criteria, but not dead in those where a whole-brain criteria is applied. Brain stem death has a lower burden of proof than whole-brain death. ${ }^{8}$

This article aims to report on awareness, knowledge, attitude and practice regarding organ donation among the medical teachers and students pursuing post-graduation at BJ Medical College, Civil Hospital Ahmedabad.

\section{MATERIALS AND METHODS}

Randomly, a total of 100 participants are chosen for this study among whom 50 are medical teachers and 50 are students pursuing post-graduation. Multiple choice questionnaire was distributed among them to respond. Answers were framed to assess the awareness, knowledge, attitude and practice. The clearence of Human Institutional Ethical Committee was obtained. Data thus collected were analyzed by Microsoft Excel Software.

\section{RESULTS}

Collected data has been presented in tabulated form as shown in Table 1.

Table 1 Tabulated form of variables

\begin{tabular}{|c|c|c|c|c|c|}
\hline S.No. & Question & Response & $\begin{array}{l}\text { Total } \\
\text { percentage }\end{array}$ & $\begin{array}{l}\text { Percentage } \\
\text { among } \\
\text { Medical } \\
\text { Teachers }\end{array}$ & $\begin{array}{l}\text { Percentage } \\
\text { among } \\
\text { student } \\
\text { pursuing } \\
\text { post-- } \\
\text { graduation }\end{array}$ \\
\hline \multirow[t]{3}{*}{$\mathbf{1}$} & \multirow{3}{*}{$\begin{array}{l}\text { Have you ever gone through } \\
\text { provisions of Transplantation of } \\
\text { human organ \& tissue act, } 1994 \\
\text { ? }\end{array}$} & $\begin{array}{l}\text { Yes } \\
\text { No }\end{array}$ & $\begin{array}{l}33.00 \% \\
47.00 \%\end{array}$ & $\begin{array}{l}22.00 \% \\
17.00 \%\end{array}$ & $\begin{array}{l}11.00 \% \\
30.00 \%\end{array}$ \\
\hline & & Some extent & $14.00 \%$ & $10.00 \%$ & $4.00 \%$ \\
\hline & & Not Exactly & $6.00 \%$ & $1.00 \%$ & $5.00 \%$ \\
\hline \multirow[t]{4}{*}{2} & \multirow{4}{*}{$\begin{array}{l}\text { Which of the following does not } \\
\text { come under human } \begin{array}{c}\text { organ } \\
\text { transplantation }\end{array} \text { \& } \\
\text { act,1994? }\end{array}$} & Hair & $18.00 \%$ & $10.00 \%$ & $8.00 \%$ \\
\hline & & Skin & Nil & Nil & Nil \\
\hline & & Blood & $14.00 \%$ & $10.00 \%$ & $4.00 \%$ \\
\hline & & All Of the above & $68.00 \%$ & $40.00 \%$ & $28.00 \%$ \\
\hline \multirow[t]{3}{*}{3} & \multirow{3}{*}{$\begin{array}{l}\text { According to } \\
\text { transplantation act of } 1994, \\
\text { what is the punishment for the } \\
\text { doctor if found guilty of } \\
\text { removing organs without } \\
\text { authority? }\end{array}$} & $\begin{array}{l}5 \text { year \& Rs } \\
10,000 \text { fine }\end{array}$ & $24.00 \%$ & $10.00 \%$ & $14.00 \%$ \\
\hline & & $\begin{array}{l}2 \text { Year \& Rs } \\
10,000 \text { Fine }\end{array}$ & $11.00 \%$ & $10.00 \%$ & $1.00 \%$ \\
\hline & & $\begin{array}{l}10 \text { Year \& Rs } \\
10,000 \text { Fine }\end{array}$ & $24.00 \%$ & $15.00 \%$ & $9.00 \%$ \\
\hline
\end{tabular}




\begin{tabular}{|c|c|c|c|c|c|}
\hline & & $\begin{array}{l}10 \text { Year \& Fine } \\
\text { up to Ks. } 20 \\
\text { lakhs }\end{array}$ & $41.00 \%$ & $30.00 \%$ & $11.00 \%$ \\
\hline \multirow[t]{4}{*}{4} & \multirow{4}{*}{$\begin{array}{l}\text { Which disease affected donor } \\
\text { cannot donate organ? }\end{array}$} & HIV & $11.00 \%$ & $9.00 \%$ & $2.00 \%$ \\
\hline & & Hepatitis B & Nil & Nil & Nil \\
\hline & & Diabetes & Nil & Nil & Nil \\
\hline & & All Of the above & $89.00 \%$ & $45.00 \%$ & $44.00 \%$ \\
\hline \multirow[t]{2}{*}{5} & \multirow{2}{*}{$\begin{array}{l}\text { Have you ever motivated the } \\
\text { paticnt's relative for organ } \\
\text { donation during your practice? }\end{array}$} & Yes & $68.00 \%$ & $30.00 \%$ & $38.00 \%$ \\
\hline & & No & $32.00 \%$ & $20.00 \%$ & $12.00 \%$ \\
\hline \multirow[t]{4}{*}{6} & \multirow{4}{*}{$\begin{array}{l}\text { Is there any brain death } \\
\text { declaration committee existing } \\
\text { in your institute? }\end{array}$} & Yes & $31.00 \%$ & $25.00 \%$ & $6.00 \%$ \\
\hline & & No & $15.00 \%$ & $10.00 \%$ & $5.00 \%$ \\
\hline & & May be & $14.00 \%$ & $9.00 \%$ & $5.00 \%$ \\
\hline & & Don't know & $40.00 \%$ & $10.00 \%$ & $20.00 \%$ \\
\hline \multirow[t]{4}{*}{7} & \multirow{4}{*}{$\begin{array}{l}\text { Which of the following criteria } \\
\text { is not included for declaration } \\
\text { of brain death? }\end{array}$} & Apnea Test & $33.00 \%$ & $20.00 \%$ & $13.00 \%$ \\
\hline & & $\begin{array}{l}\text { Brain } \\
\text { reflex }\end{array}$ & $18.00 \%$ & $12.00 \%$ & $6.00 \%$ \\
\hline & & EEG & $18.00 \%$ & $14.00 \%$ & $4.00 \%$ \\
\hline & & All Of the above & $31.00 \%$ & $20.00 \%$ & $11.00 \%$ \\
\hline \multirow[t]{5}{*}{8} & \multirow{5}{*}{$\begin{array}{l}\text { If you find any brain death } \\
\text { patient and relative insist for } \\
\text { organ donation, then whom will } \\
\text { you contact first? }\end{array}$} & $\begin{array}{l}\text { Medical } \\
\text { superintendent }\end{array}$ & $13.00 \%$ & $9.00 \%$ & $4.00 \%$ \\
\hline & & $\mathrm{IKD}$ & $24.00 \%$ & $14.00 \%$ & $10.00 \%$ \\
\hline & & Don't know & $53.00 \%$ & $20.00 \%$ & $33.00 \%$ \\
\hline & & Treating doctor & $4.00 \%$ & $1.00 \%$ & $3.00 \%$ \\
\hline & & $\begin{array}{l}\text { Forensic } \\
\text { medicine } \\
\text { Department }\end{array}$ & $6.00 \%$ & $1.00 \%$ & $5.00 \%$ \\
\hline \multirow[t]{4}{*}{9} & \multirow[t]{4}{*}{$\begin{array}{l}\text { How you promote } \& \text { motivate } \\
\text { the people for organ donation? }\end{array}$} & $\begin{array}{l}\text { Poster-paper } \\
\text { Material }\end{array}$ & $18.00 \%$ & $10.00 \%$ & $8.00 \%$ \\
\hline & & Media & $18.00 \%$ & $10.00 \%$ & $8.00 \%$ \\
\hline & & $\begin{array}{l}\text { one to one } \\
\text { counselling }\end{array}$ & $60.00 \%$ & $42.00 \%$ & $28.00 \%$ \\
\hline & & $\begin{array}{l}\text { Don't want to } \\
\text { promote }\end{array}$ & $4.00 \%$ & $1.00 \%$ & $3.00 \%$ \\
\hline \multirow[t]{4}{*}{10} & \multirow{4}{*}{$\begin{array}{l}\text { What is the age limit for } \\
\text { donating kidney? }\end{array}$} & $18-55$ year & $69.00 \%$ & $60.00 \%$ & $9.00 \%$ \\
\hline & & No age limit & $18.00 \%$ & $6.00 \%$ & $12.00 \%$ \\
\hline & & Above 18 year & $7.00 \%$ & $3.00 \%$ & $4.00 \%$ \\
\hline & & Below 18 year & $6.00 \%$ & $1.00 \%$ & $5.00 \%$ \\
\hline \multirow[t]{4}{*}{11} & \multirow{4}{*}{$\begin{array}{l}\text { Are you willing to donate your } \\
\text { own organ? }\end{array}$} & Yes & $55.00 \%$ & $30.00 \%$ & $25.00 \%$ \\
\hline & & No & & & \\
\hline & & Will think about it & $40.00 \%$ & $31.00 \%$ & $9.00 \%$ \\
\hline & & $\begin{array}{l}\text { My religion not } \\
\text { permit }\end{array}$ & $3.00 \%$ & $1.00 \%$ & $2.00 \%$ \\
\hline \multirow[t]{4}{*}{12} & \multirow{4}{*}{$\begin{array}{l}\text { Which live relative can donate } \\
\text { liver to the recipient? }\end{array}$} & Wife & $17.00 \%$ & $11.00 \%$ & $7.00 \%$ \\
\hline & & Cousin brother & $1.00 \%$ & $0.00 \%$ & $1.00 \%$ \\
\hline & & Sister in Law & $5.00 \%$ & $2.00 \%$ & $3.00 \%$ \\
\hline & & All of the above & $77.00 \%$ & $65.00 \%$ & $12.00 \%$ \\
\hline
\end{tabular}




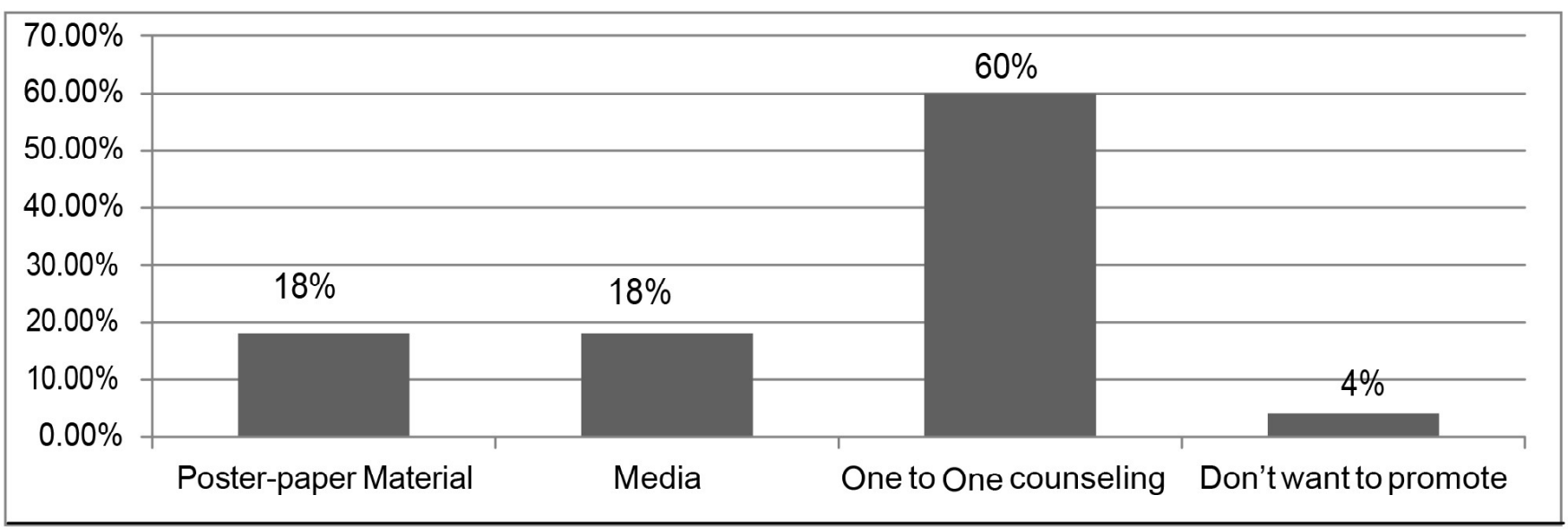

Figure 1 Preferred survey type by subjects involved in this study regarding the promotion \& motivation of the people for organ donation

\section{DISCUSSION}

In the clause of awareness and knowledge foundation, only $33 \%$ have gone through the provisions of Transplantation of Human Organ and Tissue Act, 1994. Among them 22\% are medical teachers and $11 \%$ are students pursuing postgraduation. Among them only $14 \%$ have gone through some extent of the provisions while $6 \%$ have not gone through the provisions. However continuous medical education and healthcare professional awareness camp can boost up this number. Looking on the attitude foundation major factor is the motivation for organ donation. $32 \%$ of the subjects never motivated the end stage organ disease affected patient's relative. Even $20 \%$ of medical teacher have never motivated the relative. In this clause awareness about the legislative procedure and intention for welfare of the society is needed. By motivation definitely there will be increase in the number of organ donation practice. Only $31 \%$ of the subjects know that the brain death declaration committee exists in the institute. Also the awareness and knowledge about the proper legislative procedure is required to increase the organ donation percentage in brain death deceased.

India enacted a law in 1994 to legalize the recognition of brain-stem death. Maharashtra has recently mandated the notification of brain-dead cases. ${ }^{9}$ The Government Resolution underlines the responsibilities of hospitals registered under the Transplantation of Human Organs (THO) Act 1994, that is, they are authorized transplant centres. As a large number of brain-deaths occur in hospitals not authorized to do transplants, the appropriate authority (Director of Health Services) has registered all hospitals in the state that have an operation theatre and ICU as Non-Transplant Organ Retrieval Centres (NTORCs). ${ }^{10}$ These hospitals are permitted to certify brain- death as per the prescribed procedure and then conduct organ retrieval for therapeutic purposes; however, they are not permitted to perform an actual transplantation. Thus, it is mandatory now for all NTORCs and authorized transplant centres in the state to certify and notify the brain-death cases to the Zonal Transplantation Co-ordination committee. This is a strong step to streamline the procedure for cadaveric organ retrieval and transplantation. In India, there is no legal definition of death. Section 46 of the Indian Penal Code states, "the word 'death', denotes death of a human being unless the contrary appears from the context". India follows the UK practice and considers death as equivalent to brain stem death. Medically and legally, the patient is dead, if brain stem death (brain death is used as a synonym for the latter) has been certified. The doctors involved in the diagnosis should in no way be connected with the transplant surgeries concerning the 'brain-stem dead' cadavers. The certification should be done on the laid out forms (Form No. 8) as per the Transplantation of Human Organs Act. The declaration of brain death must be recorded in the medical notes with the date and time. The legal time of death is the time at which the second prescribed clinical tests are carried out. Comprehensive reviews of brain stem death and brain death from an Indian perspective have also been documented. ${ }^{11-13}$ Currently, America has around 1,20,000 people waitlisted for organs. This is something private players in the US have also tried to raise awareness about. For instance, in 2013, Facebook allowed users to add their "donor status" to their profiles which lead to a spike in registrations. More recently, Apple offered its users in the US to sign up as donors through their iPhones as a part of their iOS 10 software update. Brazil tried to implement the presumed consent model for organ donation in 1997 only to repeal the law 8 years later. The initiative faced heavy criticism and was widely distrusted by the general public who feared that their organs would be removed before they were declared clinically dead. These protests forced Brazil to go back to the opt-in system and its current donation rate is 16 per one million people.

\section{CONCLUSION}

By research and assessment among the medical teachers and students pursuing post-graduation, we found out that there is gap between the participant and society related to knowledge, attitude and practice related to organ donation. 
Continuous Medical education \& training including awareness can bring the change in the practice of organ donation, their associating legislative procedure for the well being of the patient suffering from end stage organ disease. Motivation and promotion throughout the community by the healthcare providers is essential in the current scenario of organ donation practice. Newer healthcare promotion technology instruments on social media can bolster the awareness and legal knowledge among the medical fraternity and society.

Conflict of interest: None

Ethical clearance: Taken.

Source of Funding: None declared.

Contribution of authors: We declare that this work was done by the author(s) in this article and all liabilities pertaining to claim relating to the content of this article will be borne by the authors. The study was conceived and designed by Dr Manjit Nayak; data collection and analysis by Dr Manjit Nayak, Dr H.T Khubchandani, Dr. Kalpesh Patani and Dr. Tikendra Dewangan.

\section{REFERENCES}

1. Navin Sumana, Shroff Sunil, Niranjan Sujatha. Organ donation in India. [cited 2019 March 11]; Available from: URL:http:/www.mohanfoundation.org/organ-donationtransplant-resources/organ-donation-in-india.asp

2. Government of India. Transplantation of human organs act central act. [cited 2019 March 21]; Available from: URL:http://www.medindianet/tho/thobill1.asp

3. The Gazette of India. Transplantation of human organs rules. [cited 2019 march 25]; Available from: URL:http:/ /wwwmedindianet/indian_health_act/TheTransplantation-of-Human-Örgan-Rüles-1995-

\section{Definitions.htm}

4. The Gazette of India. Extraordinary transplantation of human organs and tissues rules (thot). Ministry of Health and Family Welfare. [cited 2019 March 11]; Available from: URL:https://mohfw.gov.in/sites/default/files/ THOA-amendment on 2011

5. Radhakrishna K. Accidental Deaths and Suicides in India 2013. National Crime Records Bureau. Ministry of Home Affairs. New Delhi: National Crime Records Bureau; 2015. p. 21-33.

6. Nair-Collins M. Clinical and ethical perspectives on brain death. Dove Press 2015;69-80.

7. Smith M. Brain death. Time for an international consensus. Br J anaesth 2012;108.

8. Joffe AR. The neurological determination of death. What does it really mean. Issues Law Med 2007;119.

9. Andrew A, Jenny B. brain dead donor. [cited 2019 March 25]; Available from: URL:http:/www.telegraph.co.uk/ news/uknews/1353436/Can-brain-dead-donors.respond.html

10. Wijdicks EF, Pfeifer EA. Neuropathology of brain death in the modern transplant era. Neurology 2008;70:1234.

11. Sade RM. Brain death, cardiac death, and the dead donor rule. J s c Med Assoc 2011;107:146.

12. Gostin LO. Legal and ethical responsibilities following brain death. The McMath and Munoz cases. JAMA 2014;311:903.

13. Simar S. organ donation and transplantation. [cited 2017 Aug]; Available from: URL:https://sites.ndtv.com/ moretogive/organ-donation-what- -are-doing othercountries 
